\title{
Analysis of Knowledge Building in a Virtual Learning Community from the Pedagogical Use of the Visibility
}

\author{
Diego Díaz, Katerin Farieta, and Andrés Mena
}

\begin{abstract}
This paper presents a proposal that contributed at macro-project named VisibiliTIC. The aim was to describe the dynamic of a virtual learning community in relation to the Knowledge Building process (KB) and collaborative work, based on the pedagogical use of the visibility of academic production.

The analysis set out from a qualitative approach with a descriptive scope. The population were students of the courses Virtual Education Unit Manuela Beltrán University (Cajicá-Colombia) and the sample was taken from the Ergonomics subject, in which two groups were classified in: experimental and comparison. The experimental design includes an independent variable (Visibility), and the dependent variable (Knowledge Building). In the comparison group is used a traditional strategy: the Forum, while that in the Experimental group is used a visibility strategy: the "Wall". This last strategy enables significantly development of the levels of $(\mathrm{KB})$ in this group.

In this study, the ATLAS.ti program was used to do Content Analysis. Here is did a comparison of academic production of students in each group where were identified the levels of $(\mathrm{KB})$.

Is identified that the teaching strategy the "Wall" based on the visibility, generated a strong impact among students of these communities, generating greater participation and intellectual production. This process generated higher levels of $(\mathrm{KB})$ in the Experimental group than the Comparison.
\end{abstract}

Index Terms - Knowledge building, analysis, virtual learning community and VisibiliTIC.

\section{INTRODUCTION}

Today, the educational computing research highlights the necessity to identify the dynamics of the process of learning in virtual environments. According to the above, in this context, the researchers try to describe the technological developments and pedagogical designs that promote participatory learning settings where coexist a series of interactions between the apprentice subject, the learning object, the media and the teaching strategies that influence and facilitate this process.

The Virtual learning environments are understood as scenarios where relationships between teachers and students are consolidated, in order to establish teaching strategies, make new didactic proposals to thematic contents and provide solutions to academic goals in the virtual subjects. These scenarios can be used in virtual education in all its presentations: e-learning, b-learning and m-learning [1].

Manuscript received July 30, 2014; revised October 30, 2014.

Diego Díaz and Katerin Farieta are with Manuela Beltrán University, Colombia (e-mail: diego.diaz@umb.edu.co, katerin.farieta@umb.edu.co).

Andrés Mena is with Universidad Manela Beltrán, Colombia (e-mail: andres.mena@umb.edu.co).
Based on the above, this proposal shows a strategy that describes the dynamics of Knowledge Building in a virtual learning community in relation to the pedagogical use of the visibility, using teaching strategies to foster this variable. This aims to adapt in the current models of teaching and learning in virtual environments.

In recent studies [1]-[4], it has been identified that, there is a relationship between student's academic production, that is, Knowledge Building and a collaborative work that has not been visible among them. Using teaching strategies based on the visibility, generated a strong impact in these students of these virtual learning communities, generating greater participation and intellectual production.

Also, it has been determined that, there are not scientific studies where relate the visibility and $(\mathrm{KB})$ in virtual communities of learning, and there are not methodological proposals where have been described systematically this relationship.

The Research Group has as hypothesis: the visibility of the academic production student enables the collaboration generating greater interest and strengthening the (KB).

The research setting is the macro-project named VisibiliTIC: Visibility of academic production of a virtual learning community, developed in the Virtual Unit of the Manuela Beltrán University in Cajicá Colombia. This macro-project considers the transformation of education from the use of ICT in relation Knowledge Building (KB), Collaborative Work (CW) and pedagogical use of the visibility in a virtual learning community [4].

The population belongs to students of this Virtual Unit and the sample was taken from the Ergonomics subject, classified in two groups: experimental and comparison. The experimental design includes an independent variable (Visibility), and the dependent variable (Knowledge Building).

The sample was selected with UCINET, a program used to social network analysis. ATLAS.TI is being used content analysis of the sample academic products.

This proposal methodological aims to develop the specific objectives of VisibiliTIC, in relation to (KB) and the pedagogical use of Visibility:

1) Describe the process of $(\mathrm{KB})$ and collaborative work.

2) Determine the relationship between the visibility of academic production and (KB) and collaborative work.

This macro-project has as educational setting, the VirtualNet 2.0 platform, on which is used the Web 2.0 tools, making it more friendlier, providing an interaction and integration more dynamic between the actors involved (teachers, tutors, students, researchers, and others) and the teaching and learning processes.

It is intended that the proposal methodology serves as a 
guide for future projects on which the student's formation is constituted as the central protagonist of the digital learning through social networks, not only recognizing the knowledge production process in a unidirectional relationship teacher->student; but in a Bidirectional relationship student--->teacher--->student, describing collaborative work possibilities to knowledge building. Sometimes, the academic production of the students, become unseen to their classmates. This situation does not enable (KB), the optimization of resources and the strategies that enhance the learning environment.

\section{CONCEPTUAL REFERENT}

In this part, is important to identify the key concepts and theories for the development of this macro-project in a general way and of this Analysis in particular.

Accordingly, it was divided in: 1) The VirtualNet 2.0 Platform as technological resource and 2) Visibility, Knowledge Building as the variables of the research.

\section{A. VirtualNet 2.0 Platform as Context of Research}

This Collaborative Learning platform is understood as didactic tool designed by the Manuela Beltrán University Technology Team, to provide to all students, teachers, researchers and administrative staff, a virtual campus that incorporates the benefits of Web 2.0 for virtual education.

This platform has the next characteristics:

- List of contents organized in a hierarchical manner which contributes to the visualization and organization of information controlled by the teacher.

- Configuration of customized activities on which a percentage value is assigned and reflected in the section "Hoja de Calificaciones" in the platform.

- Guidance to each student of the classroom, identifying the active or passive participation of them in each subject.

- Statistical reports of the subject at different times and registry of user participation in the activities proposed.

- Use native elements of modern browsers.

- Individual mail for each student in each subject on the platform.

- Capacity to build different contents and embedded elements of web 2.0.

- Results Report Validation through the use of QR codes.

- Apps for mobile devices, allowing access to teachers and students in the development of the activities of the subject (see Fig. 1).

\section{B. Visibility}

In previous and external researches, this variable was not taken as element of pedagogical analysis of the learning processes in virtual communities, for this reason the Research Group in accordance with [5] and [6] define this variable as a social phenomenon that affects the dynamics of communities, in which the students and teachers gain a social and academic recognition according to their occupied position within a group and the perception that other members have on the individual within the subject.

In accordance with [5], this macro-project shows three perspectives about the pedagogical use of visibility:

- Positive Visibility: occurs when the individual is perceived by other individuals within a group as facilitator-builder in a learning process.

- Negative Visibility: occurs when an individual is perceived by other individuals as having a negative effect on the learning process of a group.

- Social Visibility: occurs when the individual occupies a space within the group and his presence is significantly visible within the group [5] in [3].

The Table I shows the Analytic Categories that were identified by this variable accordance with [2].

TABLE I: CATEGORIES DESCRIPTION: VISIBILITY

\begin{tabular}{|c|c|}
\hline Category & Meaning \\
\hline $\begin{array}{l}\text { Individual } \\
\text { Visibility in the } \\
\text { group }\end{array}$ & $\begin{array}{l}\text { Identified by the leadership Network instrument. } \\
\text { Example: In cooperative activities, with who would you } \\
\text { work? [5]. }\end{array}$ \\
\hline Role & Responsibilities, leadership, participation [5] \\
\hline $\begin{array}{l}\text { Groups } \\
\text { formation }\end{array}$ & $\begin{array}{l}\text { It is proposed by the Teacher or the students / Group } \\
\text { identity [5] }\end{array}$ \\
\hline $\begin{array}{l}\text { Individual work } \\
\text { recognition }\end{array}$ & $\begin{array}{l}\text { Socialization of the individual contributions to the } \\
\text { group [5]. }\end{array}$ \\
\hline Patterns & $\begin{array}{l}\text { Positive visibility, when the group perceives that the } \\
\text { student contributes constructively to the activities and } \\
\text { development of the course [5] }\end{array}$ \\
\hline $\begin{array}{l}\text { Pedagogical } \\
\text { strategy Design }\end{array}$ & Pedagogical use of the visibility. \\
\hline Interaction & $\begin{array}{l}\text { Identifiable from the observation of Group action/ and } \\
\text { interaction (subject-subject, subject-objet). The skill to } \\
\text { make visible the public. }\end{array}$ \\
\hline Resource use & Platform VirtualNET 2.0, Example: "Boletín" \\
\hline
\end{tabular}

\section{Knowledge Building}

TABLE II: CATEGORIES DESCRIPTION: KNOWLEDGE BUILDING

\begin{tabular}{|l|l|}
\hline Category & Meaning \\
\hline Reference & $\begin{array}{l}\text { Relates an actor's new contribution to an existing content } \\
\text { [7]. }\end{array}$ \\
\hline $\begin{array}{l}\text { Solving } \\
\text { Problem }\end{array}$ & $\begin{array}{l}\text { It is understood as the subject's ability to define a } \\
\text { conceptual structure to solve a problem situation. [8]. }\end{array}$ \\
\hline $\begin{array}{l}\text { Collaboration } \\
\text { It is generated from technological support and reference. } \\
\text { Influence to the transformation of academic products ([8] } \\
\text { and [9]). }\end{array}$ \\
\hline $\begin{array}{l}\text { Pedagogical } \\
\text { strategy } \\
\text { Design }\end{array}$ & $\begin{array}{l}\text { It is understood as a potential technological and } \\
\text { Pedagogical Dimension [10]. }\end{array}$ \\
\hline $\begin{array}{l}\text { Technologica } \\
\text { and real } \\
\text { pedagogical } \\
\text { dimension }\end{array}$ & $\begin{array}{l}\text { Interactivity between professor - students - contents. In } \\
\text { particular scenarios. }\end{array}$ \\
\hline
\end{tabular}

This variable is established as analysis element of the academic production of the actors involved in a virtual 
learning community. According with [7], knowledge building is understood as a progressive process that emerges from the relationship between the contents to be learned (Topics), the guide subject (Tutor Manager) and apprentice fellow.

TABLE III: CATEGORIES OF ANALYSIS FOR THE LEVEL OF KNOWLEDGE BUILDING

\begin{tabular}{|c|c|}
\hline \multicolumn{2}{|r|}{ BUILDING } \\
\hline Category & Concept \\
\hline $\begin{array}{l}\text { Sharing/Comparison of } \\
\text { information }\end{array}$ & $\begin{array}{l}\text { Stage one operations include: } \\
\text {--A statement, observation or opinion. } \\
\text {--A statement of agreement from one or } \\
\text { more participants. } \\
\text {--Corroborating examples provided by one } \\
\text { or more participants. } \\
\text {--Asking and answering questions to clarify } \\
\text { details of statements. } \\
\text { Definition, description, or identification of a } \\
\text { problem. }\end{array}$ \\
\hline $\begin{array}{l}\text { The discovery and } \\
\text { exploration } \\
\text { dissonance of } \\
\text { inconsistency among } \\
\text { ideas, concepts or } \\
\text { statements }\end{array}$ & $\begin{array}{l}\text { This is the operation called cognitive } \\
\text { dissonance, defined as an inconsistency } \\
\text { between a new observation and the learner's } \\
\text { existing framework of knowledge and } \\
\text { thinking skills. } \\
\text {--Identifying and stating areas of } \\
\text { disagreement. } \\
\text {--Asking and answering questions to clarify } \\
\text { the source and extent of disagreement. } \\
\text {--Restating the participant's position, and } \\
\text { possibly advancing arguments or } \\
\text { considerations in its support by references to } \\
\text { the participant's experience, literature, } \\
\text { formal data collected, or relevant proposals } \\
\text { of metaphor or analogy to illustrate the point } \\
\text { of view. }\end{array}$ \\
\hline $\begin{array}{l}\text { Negotiation of } \\
\text { meaning/co-constructio } \\
n \text { of knowledge }\end{array}$ & $\begin{array}{l}\text {--Negotiation or clarification of the meaning } \\
\text { of terms. } \\
\text {--Negotiation of the relative weight to be } \\
\text { assigned to types of argument. } \\
\text {--Identification of areas of agreement or } \\
\text { overlap among conflicting concepts. } \\
\text {--Proposal and negotiation of new } \\
\text { statements embodying compromise, } \\
\text { co-construction. } \\
\text {--Proposal of integrating or accommodating, } \\
\text { metaphors or analogies. }\end{array}$ \\
\hline $\begin{array}{l}\text { Testing and } \\
\text { modification of } \\
\text { proposed synthesis or } \\
\text { co-construction }\end{array}$ & $\begin{array}{l}\text {--Testing the proposed synthesis against } \\
\text { past experience which shared by the } \\
\text { participants } \\
\text {--Testing against existing cognitive schema } \\
\text {--Testing against personal experience } \\
\text {--Testing against collected formal data } \\
\text {--Testing against contradictory testimony in } \\
\text { the literature }\end{array}$ \\
\hline $\begin{array}{l}\text { Agreement } \\
\text { statement(s)/application } \\
\text { s of newly } \\
\text { Constructed meaning }\end{array}$ & $\begin{array}{l}\text {--Summarization of agreement(s). } \\
\text {--Applications of new knowledge. } \\
\text {--Metacognitive statements by the } \\
\text { participants illustrating their understanding } \\
\text { that their knowledge or ways of thinking } \\
\text { (cognitive schema) have changed as a result } \\
\text { of the interaction. }\end{array}$ \\
\hline
\end{tabular}

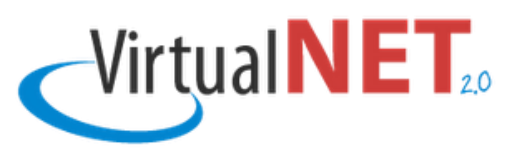

Fig. 1. Apps of the VirtualNet 2.0 platform to smart mobile.
The Table II shows the Analytic Categories that were identified by this variable accordance with [2].

The categories described from [11] are considered for this analysis. These are understood as analytical elements for the evaluation of academic production between actors (teachers and students) and these were used for Content Analysis.

The Table III shows the Analytic Categories that were identified by this variable accordance with [11].

\section{Proposal MethodologicAl}

The research methodology is qualitative with descriptive purpose. Its design is experimental, where the independent variable is the visibility and the dependent variable is the Knowledge Building.

The next diagram, presents to Analysis of $(K B)$ from the pedagogical use of the visibility, (see Fig. 2).

The Analysis is proposed, from the following processes:

\section{A. Variables Systematization}

Literature review in books, book chapters and scientific journals to:

- Structure and conceptualize the variables.

- Define the categories that compose each variable (Visibility and Knowledge Building). Take into account the specific objectives of the macro-project VisibiliTIC.

\section{B. Definition of the Categories of Knowledge Building}

In this part was establishing the categories [2] and the levels of (KB) [11] (see Table II and Table III).

\section{Design of Teaching Strategy to the Analysis}

The manager-tutor with the Research Group proposed the design of the teaching strategy based in Problem Based Learning (PBL) accordance with [12] and [13] based on:

\section{1) A theoretical dimension}

In the literature review, Problem Based Learning (PBL) was identified as alternative and innovative strategy to virtual environments which closely relates with Knowledge Building, influencing, in a significant development of this variable [14]. See Fig. 2.

\section{2) An in situ dimension}

The teacher as manager-tutor [15] developed the contents of the Ergonomics subject, around a problem situations (real life case) oriented to comply with the proposed competences of the course. See Topic 1, 2, 3 and 4 and Activities in Fig. 2.

\section{Review of the "Wall" Strategy for the Pedagogical Use of Visibility}

The "Wall" is understood as an element that has the same characteristics of an academic forum. In that, is published the progress of academic activities of the students, with aims to make visible academic production between group members. This tool is understood to as interactive setting where the actors must use elements of visibility as interactive resources, symbols, icons, video, graphics, size and color of the typeface. This action improves the academic production quality and the collaborative interaction.

In both groups (Comparison and Experimental) the PBL strategy was developed but in the Experimental group is 
complemented by the use of the "Wall" as a visibility instrument from two moments: 1 . the opening of a collaborative participation scene and 2 . the actions of the manager-tutor to promote interaction. The academic production is similar for both groups, but is more visible in the Experimental group than the Comparison. In the first group is developed higher level of knowledge Building.

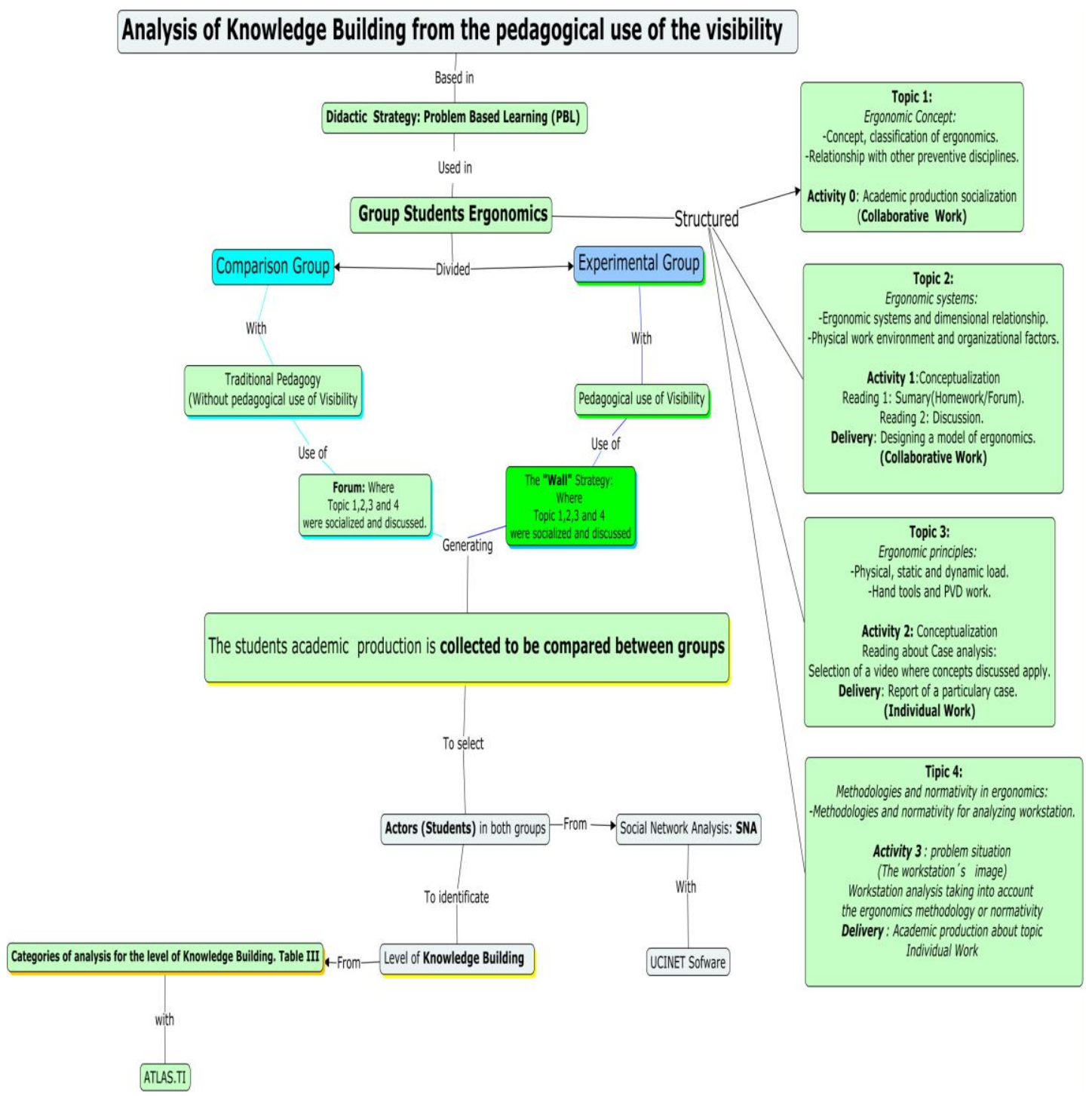

Fig. 2. Experimental design.

\section{E. Data Collection (Selection Criteria of the Population and Sample)}

\section{1) Population}

The population is defined from students Ergonomics. In this population 2 of 4 groups were selected composed of students from various undergraduate programs. The two groups were classified as Experimental (A1) and Comparison (A2) (see Table IV):

TABLE IV: GROUPS TO ANALYSES WITHIN MACRO-PROJECT VISIBILITIC

\begin{tabular}{|c|c|c|}
\hline Group & Number of students & classification \\
\hline A1 & 170 & Experimental \\
\hline $\mathbf{A 2}$ & 169 & Comparison \\
\hline
\end{tabular}

\section{2) Sample}

The sample was selected considering the analysis of social networks (SNA) based on UCINET used in the collaborative working. The elements used for Actors selection was: graph of the interaction network of actors (see Fig. 3 and Fig. 4) and the measures of centrality of UCINET: between, closeness and degree. For this analysis, were established three centrality measures within of UCINET.

- Degree: Indicates the number of connections and / or direct relationships initiated by each actor. Reflects both the social activity of each actor as their ability to access the other actors.

- Between: Indicates the intermediate position of the actors in graph connections, identifying their role as connecting bridge.

- Closeness: It measures the average distance of each actor in comparison of the rest of the actors in the network [16]. In this way, a total sample of 54 students was selected from Experimental (A1) and Comparison (A2).

Finally, in both groups, 5 actors were chosen by the convenience criterion (they were located in graph of the interaction network of actors, taking account their position as between, closeness and degree). 
In both Fig. 3 and Fig. 4, these students are represented by a combination of a letter and number, because is the way to input the data in UCINET. See to [11]. For example, in the Fig. 3 the chosen actors were: C18, C1, D6, D15 and J25. This code represents the initial letter of first name, and the number of location in the data list.

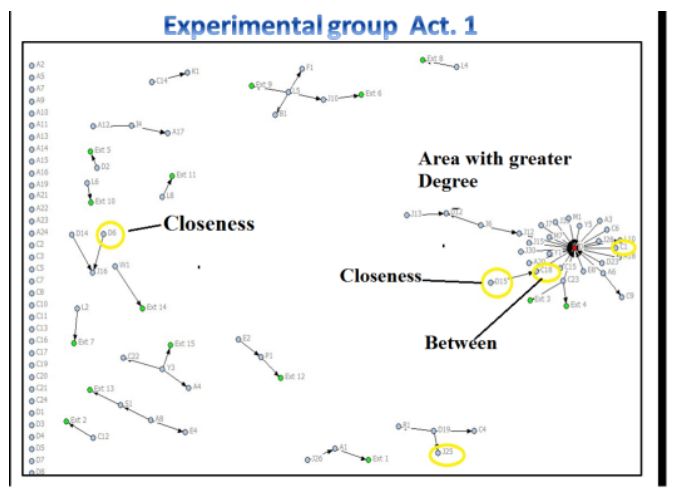

Fig. 3. Graph interaction network of actors of the comparison group. (Activity 1).

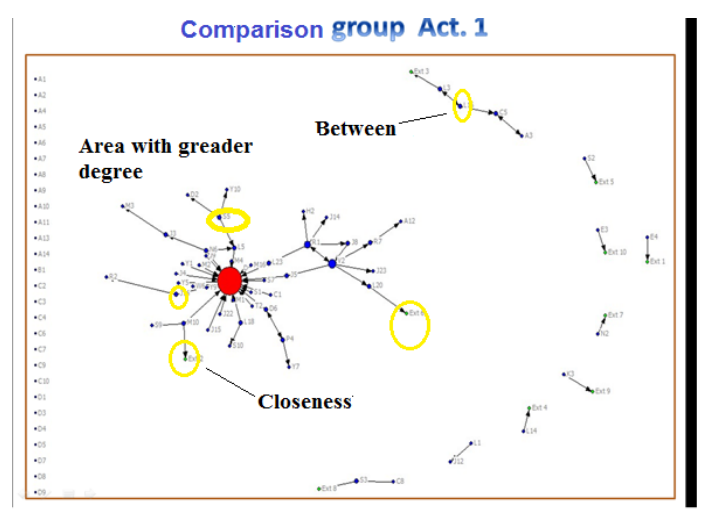

Fig. 4. Graph interaction network of actors of the experimental group. (Activity 1)

\section{F. Information Analysis: Using ATLAS.Ti}

In each group, the "Wall" and the forum (see Fig. 2) were the strategies where content analysis/discourse was did. There, the levels of Knowledge Building were identified according to [2] and [11]. ATLAS.Ti Software was used in this step.

\section{INTERPRETATION OF RESULTS}

Considering the categories of [2] and levels of Knowledge Building of ([11] (see Table II and Table III), the Content Analysis was performed with ATLAS.Ti in activity 1 of both groups and the following results were identified:

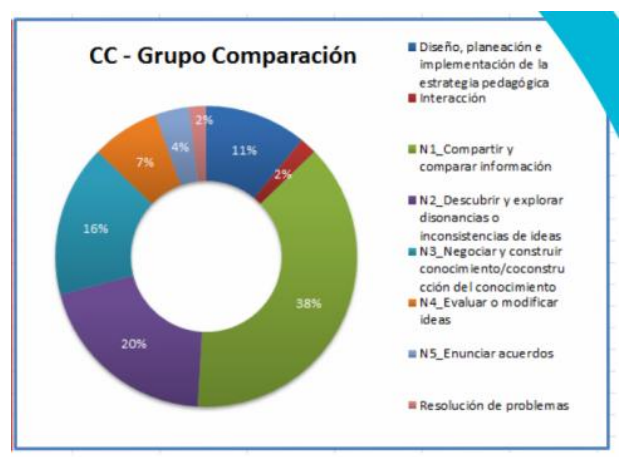

Fig. 5. Categories (Table II) and levels of knowledge building (Table III) in comparison group.

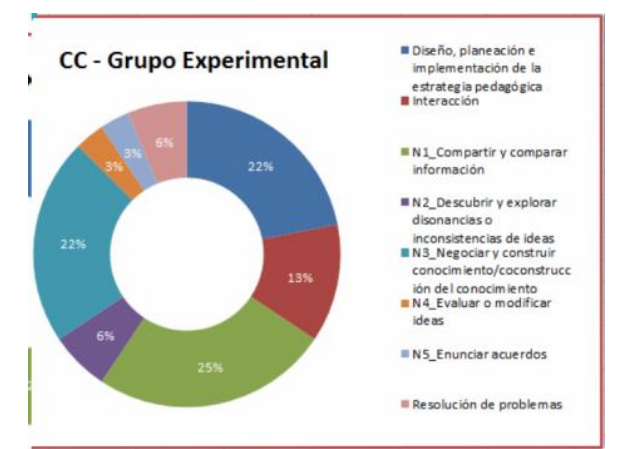

Fig. 6. Categories (Table II) and levels of knowledge building (Table III) in experimental group.

In comparison group (see Fig. 5) was identified level of Compare/share the information with $(38 \%)$ of students, showing that they were limited only to present their activities without generating comments. Level of Dissonances was identified with $(20 \%)$ of students, showing that, there was a poor participation. Solving problem category shows an interaction incipient with $(2 \%)$. In this group was used the Forum as traditional strategy. Students follow teacher's instructions strictly.

In Experimental group (see Fig. 6) was identified level of Compare/share the information with $(25 \%)$ of students, showing that they were in a particular situation where they proposed different resources to answer ergonomics activities. About Pedagogical strategy design category is observed with $(22 \%)$ of students, indicate that the visibility strategy was effective to allow levels of (KB) as the level the Negotiation of meaning/co-construction of knowledge complex with (22\%) of students, was increased. This indicates that in comparison with the other group, there is evidence of further development in the problem solving category with $(6 \%)$. Interaction category is further in this group with $(13 \%)$.

There is a further development of the levels of Knowledge Building ([11] in Experimental group than Comparison group, this fact, by the implementation of the strategy based on the pedagogical use of the visibility: "Wall".

\section{CONCLUSION}

The didactic strategies (in this case the "Wall") supported in the pedagogical use of the visibility, significantly impacted the Knowledge Building of the Experimental group than the Comparison. This analysis allows us to understand that the pedagogical use of the visibility is applicable to study Building Knowledge of the actors in a virtual learning community.

- The levels of Knowledge Building that were highlight: Sharing/Comparison of information, Negotiation of meaning/co-construction of knowledge and Agreement statement(s)/applications of newly Constructed meaning (see table III). This indicates that students developed a descriptive and critical level of information that enables them a significant academic production.

- The PBL strategy complemented the competencies development of subject Ergonomics, through the academic production of some students who contributed significantly to the proposed activity. This process was observed in each group. If there is a specific teaching 
strategy, this can promote a meaningful learning in the students.

- The strategy "Wall" as element of the visibility enabled us to identify collaborative learning among students who participated in this activity. They worked together sharing comments that encouraged discussion and agreements of meanings in the thematic content. This process was observed in Experimental group.

- The Teaching Management improved the level of comments and Knowledge Building, but still is necessary to strengthen the teaching management strategies to motivate all students to participate actively and constructively.

- In fact, the visibility of the academic production students enables the collaboration, generating greater interest and significantly developing of the levels of (KB).

\section{REFERENCES}

[1] A. Chiecher, "Aprender en la distancia...pero junto con otros. Interacciones entre tutores y alumnos en contextos virtuales de aprendizaje," Innovación Educativa Review, Instituto Politécnico Nacional, México, vol. 8, no. 45. pp. 4-19, 2008.

[2] A. Mena, D. Díaz, and K. Farieta, "Pedagogical use of the visibility in a virtual learning community as a methodological approach," presented at 6th International Conference on Education and New Learning Technologies, IATED Academy, Barcelona, 2014.

[3] B. Lacuesta and L. Catalán, "El aprendizaje basado en problemas: una herramienta para toda la vida," Agencia Laín Entralgo, Madrid, 2004 2010.

[4] C. Gunawardena et al., "Analysis of a global online debate and the development of an interaction analysis model for examining social construction of knowledge in computer conferencing," Journal Educational Computing Research, vol. 17, no. 4, pp. 397-431, 1997.

[5] D. González, "Elementos de visibilidad que propician la interacción y el trabajo colaborativo en un entorno de educación virtual," Graduation Project, Planeación, Desarrollo Y Administración de La Investigación post-program, Manuela Beltrán University, Cajicá, 2014.

[6] E. Clifford, "Social visibility," Child Development, vol. 34, no. 3, pp. 799-808, 1963.

[7] I. Álvarez, B. García, Gros, and V. Guerra, "El diseño de entornos de aprendizaje colaborativo a través del programa knowledge forum: Análisis de una experiencia," Educación Review, vol. 341, pp. 441-469, Barcelona Univesity.

[8] J. Hernández, "Visibilidad de los actores en una comunidad de aprendizaje, una mirada desde el análisis de las redes socials," UNAD, 2010.

[9] J. Hernández, A. Montoya, and A. Mena, "Dinámica de la visibilidad en una comunidad virtual de aprendizaje," Memorias XVII Congreso Internacional de Informática Educativa, TISE, 2012.

[10] J. Onrubia, "Aprender y enseñar en entornos virtuales: actividad conjunta, ayuda pedagógica y construcción del conocimient," RED Revista de Educación a Distancia. Murcia (Espain), 2005.

[11] J. Rodríguez and F. Mérida, "Guía práctica de Redes Sociales: UCINET, Sociología y análisis de las organizaciones," Unit 6 . Departament, Barcelona University.

[12] M. Bossalasco, D. Donolo, and A. Chiercher, "Indicador de construcción conjunta de conocimiento. Referencia al aporte de otro en foro de discussion," Innovación Educativa Review, México: Instituto Politécnico Nacional, vol. 9, no. 47, pp. 19-31, 2009.

[13] M. Castro, "VisibilitiC: Ergonomía bajo un ambiente virtual de aprendizaje, transformación del quehacer docente desde la investigación," RIBIE Diálogos y Saberes Review, Bogotá, 2013.

[14] S. Araujo, "El aprendizaje basado en problemas: Una nueva perspectiva de la enseñanza en la Universidad," Editorial Gedisa Barcelona, 2008.
[15] K. Roa and R. Gómez, "Construcción de conocimiento con metodología de aprendizaje basado en problemas frente al modelo tradicional, en ambiente virtual," Dialnet Review, vol. 4, no. 1, pp. $11-24,2009$

[16] L. Maldonado, "Visibilidad y formación en investigación. Estrategias para el desarrollo de competencias investigativas," Studiositas Review, vol. 2, no. 2, pp. 43-56, Bogotá, 2007.

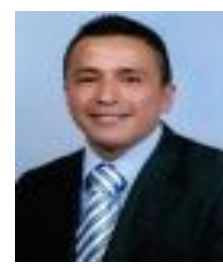

Díaz T. Diego was born in Bogotá, Colombia on May 14, 1984. He received his bachelor of science in chemistry and an Msc degree in teaching of chemistry from Pedagógica Nacional University, Colombia 2007 and 2011, respectively. He obtained his $\mathrm{PhD}$ in chemistry in from Universidad de Santiago de Chile.

His research interests include learning and teaching of sciences in different levels of education, ICT and Education, research skills development, learning in virtual education.

He has served as a chemistry teacher in different institutes. Currently, he works at the Manuela Beltrán University as a researcher teacher (Bogotá, Colombia) and is a member of the research group in educational computing research.

He has published several articles on Sciences and Educational Computer-ICT. He is currently the project leader of visibility in this University. He was awarded a grant from the Department of Science and Technology Innovation Colciencias as "Joven Investigador 2011-2012".

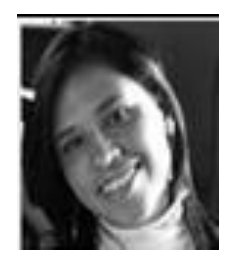

Farieta Katerin was born in Bogota, Colombia on March 21, 1983. She got her bachelor of science in chemistry and a master degree in teaching of chemistry from Pedagógica Nacional University. Her research interests include learning and teaching of sciences in different levels of education, research skills development, learning in virtual education contexts and student desertion. She has served as a coordinator of research and educational projects in different Universities. Currently, she is the director of the postgraduate specialization in research planning, development and administration at the Manuela Beltrán University (Bogotá, Colombia) and is a member of the research group in educational computing research.

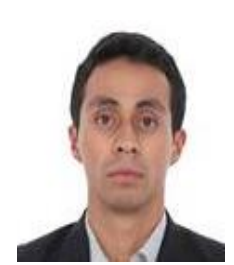

Mena G. Andrés was born in San Juan de Pasto, Colombia on August 18, 1986. He is an economist from Universidad de Nariño, Colombia 2008). He got his specialist degree in research planning from Universidad Manuela Beltrán, Colombia 2011, and his master's degree in integrated technologies and knowledge society from Universidad Nacional de Educación a Distancia, España 2013; and PhD student in education and communication from Universidad Nacional de Educación a Distancia. His major is e-learning.

He has worked at the Universidad Manela Beltrán in different positions, like a virtual tutor (2009-2010); a virtual programs (undergraduate and graduate) coordinator (2010-2013); a research coordinator (2012-at present, Bogotá, Colombia). He has published papers and has been speaker in several scenarios. Some publications are: "Pedagogical use of the visibility in a virtual learning community as a methodological approach", in Proceedings International Conference on Education and New Learning Technologies, with ISBN 978-84-617-0557-3; "Dinámica de la visibilidad en una comunidad virtual de aprendizaje", in Nuevas ideas en informática educativa, in proceedings TISE2012, with ISBN 978-956-190-793-5; and "Dynamic of interaction among actors mediated by the visibility in an online community, what's up with...?”, in Conference Proceedings CSCL 2012. The current interest are: knowledge building, social network analysis and learning strategies.

Mr. Mena is a member of UxTIC network, and has participated in meanings from RENATA network who coordinates the academic event "TICon, knowledge and technologies". 